\title{
THE SYMBOLISM AND FUNCTION OF THE WINDOW OF APPEARANCE IN THE AMARNA PERIOD*
}

\author{
SYMBOLIZM I FUNKCJA OKNA POJAWIEŃ \\ W OKRESIE AMARNEŃSKIM
}

\author{
Maria M. Kloska \\ orcid.org/0000-0003-4822-8891 \\ Wydział Historii, Uniwersytet im. A. Mickiewicza \\ ul. Uniwersytetu Poznańskiego 7, 61-614 Poznań \\ mariamkloska@gmail.com
}

\begin{abstract}
During the reign of the Amarna spouses, giving gold necklaces to royal officials took place (almost always) from the so-called Window of Appearance. From them, Akhenaten and Nefertiti, often with princesses, honoured deserved and devoted dignitaries. The popularity of the Window of Appearance closely relates to the introduction of a new religious system introduced by Akhenaten and Nefertiti. According to the new religion, Akhenaten and Nefertiti were a pair of divine twins like Shu and Tefnut, who in the Heliopolitan theology, were the children of the god Atum - replaced by Aten in Amarna. The royal couple prayed to the main solar god, while their subjects prayed to the king and queen. Since Akhenaten performed the role of a priest through whom ordinary people could pray to the god, it was necessary to create a construction that would allow the king to meet with his subjects publicly. The Window of Appearance was such architectural innovation. It was crucial because the king was an intermediator between the people and the only right sun god, Aten. The Windows of Appearance were probably located in various places in Akhetaten, including the Great Palace, the King's House, the North Palace, the Small Aten Temple and in the temples of the Sunshades of Re in the Kom el-Nana and Maru-Aten. The characteristic shape of the Window of Appearance often appears in the architecture and the art of the Amarna Period. The structure resembles the $3 h t$ hieroglyph, which is the morning sun rising between two hills. This symbol is a part of the name of the new capital 3ht-itn - The Horizon of Aten.
\end{abstract}

KEY WORDS: the Window of Appearance, Amarna palaces architecture, rewarding officials, giving gold to dignitaries, receivinig ,gold honour” collars, Amarna period, Akhenaten, Nefertiti, Akhetaten, Tel-el Amarna

\footnotetext{
* ORCID: https://orcid.org/0000-0003-4822-8891.
} 
Akhenaten and Nefertiti's reign is characterised not only by a specific iconographic style but also by types of scenes. Some representations, such as royal family's mourning after Maketaten's (and Kiya's?) death (Martin, 1974, vol. 2, pl. LXIII, p. 42-45; pl. LXVIII, p. 45-48); king and queen playing with their children $^{1}$; Nefertiti smiting the enemies of Egypt on her own (in the human form ${ }^{2}$ or as a sphin $x^{3}$ ); and the queen driving the chariot alone ${ }^{4}$; are unique and unprecedented elsewhere.

Similar phenomenon appears regarding the reliefs showing Akhenaten and Nefertiti ${ }^{5}$ while rewarding dignitaries. These scenes are one of the most characteristic representations known from the tombs' walls from Akhetaten ${ }^{6}$. During the reign of the Amarna spouses, giving gold necklaces to royal officials took place (almost always) from the so-called Window of Appearance. From them, Akhenaten and Nefertiti, often with princesses, honoured deserved and devoted dignitaries.

The Window of Appearance was the architectural element closely connected to the religious and administrative duties of the royal couple. The new capital was adapted specially for these ceremonies by placing the Windows of Appearance within its palaces.

The Egyptian term šsd $n$ h ${ }^{2} i$ defined The Window of Appearance. This phrase appeared for the first time in the Decree of Horemheb (Kruchten, 1981, p. 162, 164, 174). In the Harris Papyrus, there is a short description of the Window and its functions (Erichsen, 1933, p. 5, v. 10-11; p. 95, v. 10-11). Generally, the name Window of Appearance is mentioned in inscriptions dated to the late XVIII, XIX, and XX dynasties.

1 Vide: Steles from home altars from Akhetaten: Berlin ÄM 14145

(http://www.smb-digital.de/eMuseumPlus?service=direct/1/ResultLightboxView/result.t1.collection_lightbox. \$TspTitleImageLink.link\&sp=10\&sp=Scollection\&sp=SfieldValu$\mathrm{e} \& \mathrm{sp}=0 \& \mathrm{sp}=0 \& \mathrm{sp}=3 \& \mathrm{sp}=\mathrm{Slightbox} \_3 \mathrm{x} 4 \& \mathrm{sp}=0 \& \mathrm{sp}=\mathrm{Sdetail} \& \mathrm{sp}=0 \& \mathrm{sp}=\mathrm{F} \& \mathrm{sp}=\mathrm{T} \& \mathrm{sp}=0$ [Access: $26 \mathrm{~V}$ 2019]), Cairo JE 44865.

(http://www.globalegyptianmuseum.org/record.aspx?id=15416 [Access: 26 V 2019]).

2 Vide: Talatat from Karnak 1689-2 044904104 (Roth 2002, p. 29, fig. 6), blocks from Hermopolis MFA 64.521 and 63.260 (http://www.mfa.org/collections/object/talatat-river-scene-with-royal-barges-and-tow-boats-46198 [Access: 26 V 2019]).

${ }^{3}$ One of the reliefs in the tomb of Kheruef shows the celebration of $3^{\text {rd }}$ heb-sed of Amenhotep III where queen Tiye - Nefertiti's mother-in-law - was also shown as a sphinx trampling the enemies of Egypt (The Tomb of Kheruef, 1980, pl. XLIX).

${ }^{4}$ Nefertiti driving her chariot in Karnak (Redford, 1988, pl. XVIII.), and also in Akhetaten (Davies, 1905, vol. 2, pl. XIII, XVI; vol. 1, pl. X).

5 Not only Akhenaten was shown together with his queen in the Window of Apperaence. For example, relief from the tomb of Nebwenef in Thebes shows Ramesses II together with his wife, queen Nefertari in the Window of Appearance (Bunson, 2012, s.v. Window of Appearance, p. 473.).

${ }^{6}$ Akhetaten is the ancient Egyptian name of the modern site Tell el-Amarna. 


\section{THE DESCRIPTION OF THE WINDOW OF APPEARANCE}

The Window of Appearance can be characterised as a balcony with two high pillars on its sides. The pillars are richly decorated with rows of uraeuses and cavetto cornice. The balustrade of the balcony is quite high - it reaches half of the bellies of the royal couple. The typical detail of the Window of Appearance is a big cushion laying on the railing of the balustrade. On the reliefs, the cushion often changes its shape under the pressure of the bodies of Akhenaten and Nefertiti (fig. 6). Sometimes younger daughters of the royal couple are standing on the cushion (fig. 5).

The shape of the Window of Appearance derives from the evolution of the traditional Egyptian kiosk. Inside the kiosk the pharaoh was represented together with a goddess and/or his wife (fig. 1). The ruler seated on the throne under the baldachin of this construction. Additionally, kiosk was located on the pedestal. While seating inside the kiosk the pharaoh could receive a tribute or reward the officials. As Petra Vomberg remarks, since the beginning of the XVIII dynasty to the reign of the Amenhotep III, the kiosk extended considerably (Vomberg, 2004, p. 283). We can notice this development thanks to the triple frieze of uraeuses (fig. 3). Eventually, the kiosk transformed into the Window of Appearance in the Amarna Period. It is worth pointing out that the classic kiosk was still present during Akhenaten and Nefertiti's reign. For example, on the relief from the tomb of Meryre II the royal couple received the tribute under the classic kiosk (Davies, vol. II, pl. XXXVII, XXXVIII). Kiosks are also visible on the boats showed on the talatats from Hermopolis, on which Akhenaten (?), and Nefertiti are killing the enemies of Egypt ${ }^{7}$.

Other critical aspects connected to the Window of Appearance are the iconographic motifs located underneath. For example, on the reliefs from the tombs of Meryre II (Davies, 1905, vol. 2, pl. XXXIII), and Parennefer (Davies, 1908, vol. VI, pl. IV), the railing of the balustrade is decorated with sema-taui motif ${ }^{8}$ and representations of the captured captives. In turn, the front of other balustrades - for example from the tomb of Hui (Davies, 1905, vol. 3, pl. XVII) - is decorated with specific decoration closely resembling rounded and richly decorated fabric overhanging by the railing of the balcony. These types of iconographic motifs were discovered inside the Amarna palaces. The finding helped to locate one of the Windows in the Great Palace in Tell el-Amarna - the fact that I will describe further in the text.

${ }^{7}$ Blocks from Hermopolis - Boston: MFA 64.521 and MFA 63.260 (http://www.mfa.org/collections/ object/talatat-river-scene-with-royal-barges-and-tow-boats-46198 [Access: 26 V 2019]).

${ }^{8}$ The symbol of sema-taui means the united of the two lands, that is the connection of the Upper and the Lower Egypt. The symbol represents heraldic plants of the Nile's valley and delta - lily and papyrus, which are tied together around hieroglyph
are marked by The Sign List of Alan Gardiner, which is located In A. H. Gardiner, 1957, Egyptian Gram-
mar. Being an Introduction to the Study of Hieroglyphs, Oxford: Griffith Institute, Ashmolean Museum). 
After the analysis of the reliefs from the Amarna tombs, we may notice that the Windows of Appearance were located significantly higher than the floor level. Besides, on the relief in the tomb of Mahu, there are four-stage stairs behind the Window. Probably the royal family used these stairs to get on the balcony. According to Vomberg, the Window of Appearance was located between $1^{\text {st }}$ and $2^{\text {nd }}$ floor, which emphasised the significance of this architectural form (Vomberg, 2004, p. 282).

The preserved representations also point out to the fact that the Window of Appearance had to overlook the large courtyard. The square could accommodate many people who often accompanied honoured official.

Besides the characteristic architectural form, the Windows of Appearance have one common feature - the presence of the disk of the god Aten. The deity is represented above the heads of the royal couple and between two pillars of the balcony. The rays of the Aten, always ended with small hands, often offer Akhenaten and Nefertiti sign of life - ankh or sign of power - uas.

\section{THE WINDOWS OF APPEARANCE BEYOND AKHETATEN (IN ARCHITECTURE)}

The Windows of Appearance were found in New Kingdom palaces and mortuary temples. However, flourishing and the highest frequency of the occurrence of this architectural element falls on the Amarna Period.

The earliest Window of Appearance was found in the Mansion of Millions of Years of Hatshepsut, that is the mortuary temple of the queen/pharaoh in Deir el-Bahari (Vomberg, 2004, p. 250-252). It was located on the southern side of the upper terrace.

The architectural remains of the Windows of Appearance were (probably) found also in the palace of Amenhotep III in Malgata and the palace of Merenptah in Memphis (Vomberg, 2004, p. 252, 259). Archaeological data also indicate that the Window of Appearance was located in the palace of Ramesses II in the Ramesseum (Hölscher, 1932, p. 57, fig. 38). The only preserved Window was discovered in Medinet Habu (Vomberg, 2004, p. 261-268; Hölscher, 1932, p. 23-28, fig. 15, 18, pl. III-IV).

\section{THE LOCALISATION OF THE WINDOWS OF APPEARANCE IN AKHETATEN}

Over the years of excavations conducted in Tell el Amarna, archaeologists could not localise any Window of Appearance, which architectural form was well-known thanks to the Amarna tombs' reliefs. On the basis of these scenes, we may conclude that in the Amarna palaces we should find more than one window from which the pharaoh, together with Nefertiti and their daughters, performed their administrative duties. 
John Pendlebury, one of the Egyptologists who conducted the archaeological excavations in Akhetaten on behalf of the Egypt Exploration Society, believed that two Windows of Appearance were located in the central part of the bridge passing through the Royal Avenue, which - as we know today - stretched from the North Palace to the Nefertiti's temple of the Sunshades of Re in the Kom el-Nana complex. The archaeologist presumed that the second Window was situated above one of the entrances leading to the main courtyard in the Great Palace (Pendlebury, 1951, part III, p. 34, $43,76,78$, pl. 2, 14).

The current head of the archaeological research in Amarna, Barry Kemp, in his publication from 1976, suggested that the Window of Appearance should be located in the chamber situated in the north-east corner of the King's House (Kemp, 1976, p. 81, fig. $2 \mathrm{~A})$. This conception was confirmed by the remains of a ramp or stairs and a painting showing the captured prisoners. In his discovery he guided himself with the Window of Appearance discovered in the palace of the Ramesses III in the Medinet Habu (Kemp, 1976, p. 81-82, 88), where a wooden platform was located 2 metres above the floor level, and the central iconographic motif of the neighbouring walls were the scenes of the pharaoh victory over the foreign enemies. In the publication The city of Akhenaten and Nefertiti: Amarna and its people published in 2003, Egyptologist still supports his theory about the localisation of the Window of Appearance in the King's House (Kemp, 2003, p. 132-133, fig. 4.8). Vomberg (2004, p. 252-254, 282) agrees with Kemp's conception. She is the author of the book titled Das Erscheinungsfenster innerhalb der amarnazeitlichen Palastarchitektur: Herkunft - Entwicklung - Fortleben, which directly relates to the subject of the innovative construction of the Windows of Appearance, which appeared in the New Kingdom palaces architecture. Kemp in his article from the 1970s suggested that the Window of Appearance could also be located in the Small Aten Temple (Kemp, 1976, p. 91) - hwt Itn, The Residence of Aten. The temple was situated next to the King's House. Archaeologist localised the Window in the so-called Priests' House, which is between $2^{\text {nd }}$ and $3^{\text {rd }}$ pylon of this temple.

As suggested by Pendlebury, the Window of Appearance was also located in the Great Palace. Kemp is sure that it is the main Window in Akhetaten (Kemp, 2003, p. 138, fig. 4.12). The construction is situated on one end of the palace's axis. The second end is a throne chamber. The room with the Window overlooked the courtyard, where stood many steles. The stone ramp leading to the platform where the Window was situated was in the middle of the courtyard.

Kemp believes that the central platform with stairs discovered in Kom el-Nana complex should also be identified as the Window of Appearance (Kemp, 2003, p. 140, fig. 4.13; Vomberg, 2004, p. 257-258). Jacquelin Williamson, in her work about the Nefertiti's temple of the Sunshades of Re in the Kom el-Nana complex, drew attention to the concept of Kemp (Williamson, 2016, p. 166-168, fig. 3.6). The archaeologist guesses that the courtyard situated opposite to the platform could indeed accommodate many of the pharaoh's subjects. The nearby bakeries could feed a large group of people. However, the researcher does not state in the explicit way that the platform should be identified as the Window of Appearance. 
Kemp believes that the Window was located also in Maru-Aten (Kemp, 1995, p. 459) - the temple of the Sunshades of Re. The temple initially belonged to Kiya - the minor wife of Akhenaten - but after her death it was taken over by the eldest daughter of Akhetaten, Meritaten.

According to Kemp, the Window of Appearance was also situated in North Palace in Akhetaten (Kemp, 1995, p. 136, 146-147, fig. 4.10, 4.22), which was probably the primary residence of the royal family. At the rear of the palace, stood the throne room preceded by the column hall overlooking the courtyard. In the courtyard the ramp (or stairs) leading to the stone platform was located. This platform is identified with the main Window of Appearance of the North Palace. The Window faced the inner courtyard with the garden. From the column hall, both on the north and the south, extended corridors led to smaller the Windows of Appearance. Vomberg assumes that such concept is tempting, however, it is difficult to prove it. The scholar believes that the North Palace is located too far from the central part of Akhetaten where the ceremonies which are immortalised on the walls of the Amarna tombs took place (Vomberg, 2004, p. 256, 282).

\section{THE SYMBOLISM OF THE WINDOW OF APPEARANCE IN AKHETATEN}

The new religion introduced by Akhenaten and Nefertiti forced many changes which occurred in architecture - especially in temples and palaces. The god Aten took the shape of a solar disc (the sun was visible for each Egyptian), thus the dark shrines, characteristic for the god Amun, were no longer needed. The temples in Amarna were devoid of roofs so that solar god could enjoy gifts offered to him on the countless altars ${ }^{9}$.

Similar, though less spectacular, changes were introduced in the palace architecture. They resulted from the implementation of the new religious system in which Akhenaten and Nefertiti were a pair of divine twins like Shu and Tefnut, who, according to, Heliopolitan theology were the children of the god Atum (who was replaced by Aten in Amarna). The royal couple prayed to the main solar god, while their subjects prayed to the king and queen. For this reason, in the private houses and gardens in Akhetaten steles were showing the holy family. The same representations of god, king, queen, and princesses were immortalised in the Amarna tombs. The representations of the six daughters of the royal couple, besides being the confirmation of the spouses' fertility, performed another crucial religious function. Princesses replaced six gods of Heliopolitan Ennead: Geb and Nut, Osiris and Isis, Seth and Nephthys. The sisters, together with their parents and the god Aten, created the divine Ennead, just like the model of the nine gods from Heliopolis.

Since Akhenaten performed the role of a priest through whom ordinary people could pray to the god, it was necessary to create a construction that would allow the

\footnotetext{
${ }^{9}$ More on this subject: Vomberg, 2008, p. 64-85.
} 
king to meet with his subjects publicly. The Window of Appearance was such architectural innovation. Thanks to it, the Egyptians could see not only their pharaoh but also the whole deified family.

The Window of Appearance played a crucial role during the ceremonies of rewarding and honouring dignitaries with gold. Akhenaten and Nefertiti, often together with their daughters, were standing behind the balustrade of the Window and threw the golden necklaces towards the honoured officials in front of the crowd (fig. $2,4,5,6$.).

The shape of the typical Window of Appearance is visible on the reliefs from the Amarna tombs. The form which the architectural innovation adopted is not accidental (fig. 2). The window's railing behind which the royal family was standing, the two side pillars, and the lack of a lintel makes that the Window of Appearance has the

characteristic shape of the $3 h t$ hieroglyph

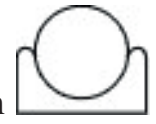
(N27), which looks like the sun rising between two hills (wadi). The Window of Appearance would be a metaphor. It should be emphasised that inside the Window we can always see the royal family and the sun with the rays ending with small hands, that is Aten. References to the $3 h t$ hieroglyph appear very often in Amarna. Of course, the very name of the new capital 3ht-itn - The horizon of Aten - contains this symbol, which nota bene is also visible in the Amarna landform - The Great Royal Wadi (where the Royal Tomb was carved). The Great Royal Wadi is located on the east, so the morning sun is rising between the two hills (Kemp, 2013, photo VI). The same metaphor regards pylons leading to the Great and Small Aten Temple in Amarna ${ }^{10}$. The symbolism of the 3ht hieroglyph can also be seen on other Amarna artefacts showing the royal family. The good examples are the steles from the home's altars ${ }^{11}$ which show royal spouses playing with their daughters. In that picture Aten is visible above and between the king and the queen.

As noted by Florence Friedman (1986, p. 101), in the Pyramid Texts it has been written that horizon - that is $3 h t-$ is a place where the king and sun god become $3 h$ a cosmic and celestial spirit/energy (Hanning, 1995, p. 11-12, s.v. 3h (j3h). The pharaoh does not die beyond the horizon but becomes the astral force. The $3 h$ hieroglyph also occurs in the Akhenaten's name: 3h-n-Itn. The entire phrase can be translated as The one, that is useful ${ }^{12}$ for Aten or The Akh of the Aten, which is The blessed spirit of the Aten. Friedman disagrees with this type of translation of the king's name. She assumes that by giving himself the name $3 h-n-I t n$, the pharaoh wanted to present himself as the solar light of his divine father (Friedman, 1986, p. 100). In addition, it should be noted that the Egyptian word which determined father, grandfather, or general an-

${ }^{10}$ The morning sun rising between two hills was also shown on the walls from the Amarna tombs. E.g.: Davies, 1908, vol. 6, pl. XX, XXX.

11 Vide supra: note 2.

12 Ibidem, s. v. Ax. 


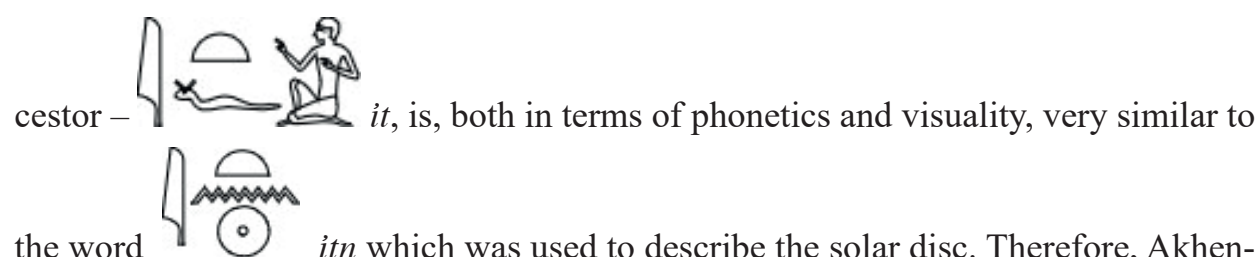
aten has to be the son of the god Aten, that is the creation of the supreme creator.

As already mentioned, in the new religion, Akhenaten and Nefertiti performed the roles of the Shu and Tefnut. According to the Coffin Texts, Atum created Shu and Tefnut from his own 3 hw (de Buck 1955, Spell 80 - II39-c-d), which is magical power (Hanning, 1995, p. 12, s.v. 3hw). Therefore, we can assume that also Aten created his children by using the cosmic and divine energy - similarly like Atum.

\section{THE FUNCTIONS OF THE WINDOW OF APPEARANCE}

As it was already mentioned, the oldest Window of Appearances is known from the mortuary temple of Hatshepsut in Deir el-Bahari. During that time, this construction had a purely religious character. The pharaoh appeared in the Window while ceremonies and rituals were taking place in the temple.

The introduction of this type of construction like the Window of Appearance closely relates to the implementation of the new belief system. The Windows had special symbolism because only the royal family could contact Aten, and the ordinary people had to pray to Akhenaten and Nefertiti. The king, as the high priest, performed the ceremonies and cultic rituals from the Window of Appearance. Therefore, the Kemp's concept regarding the smaller Window located in the Small Aten Temple can be argued easily and rationally because such type of construction should be situated in the place of worshipping the deity. Akhenaten as the head of the state celebrated (often together with his family) also another type of ceremony - he rewarded dignitaries with gold. The Window of Appearance characterized then of the cultic and administrative nature. However, it is not extraordinary since religion and ideology of royal power were closely related - to stress that Aten was present at every kind of ceremony.

It is worth noting that after the Amarna Period Windows appeared only in palaces, and they lost their cultic character completely. They were used only for formal purposes, such as honouring officials.

\section{THE CEREMONY OF REWARDING WITH GOLD}

The reliefs showing the pharaoh giving the gold to the dignitaries have been known since the Old Kingdom. One of the first of such representations comes from the mortuary temple of Sahure (V dynasty). The preserved blocks show high royal officials holding jewellery in hands which was offered to them by the ruler (Aldred, 1978, p. 13). 
Unfortunately, the figure of the pharaoh is not visible on the preserved fragments (e.g., Borchardt, 1913, vol. 2, pl. 52-54).

The scenes of giving the gold to deserved officials by the king gained popularity in the New Kingdom. Such type of reliefs are one of the most desirable and crucial motifs that were included in the autobiographies of dignitaries. They were placed on the walls in their private tombs from the middle of XVIII dynasty to the Ramesside Period (Schulman, 1988, p. 116). The majority of all scenes of rewarding with gold were created in the Amarna Period.

Honoured dignitaries were always shown surrounded by their families, friends, and other people who accompanied them during these ceremonies. Official stood opposite to the king or royal couple (in the case of scenes from Akhetaten - often the entire royal family) who, when depicted in a traditionally - was/were sitting on the throne(s) sheltered in a small kiosk, or when the scene was in the Amarna style - royal spouses stood in the Window of Appearance. Reliefs from the tomb of Vizier Ramose (TT55) are an excellent example of these two types of representations. Some scenes are kept in the traditional Egyptian style, while innovative Amarna features characterise the others. The Amenhotep III was immortalized, accompanied by the goddess Maat on the southern side of the western wall of the column hall (fig. 1). The couple is sitting on the thrones inside a small but richly decorated kiosk (Davies, 1941, pl. XXIX). Akhenaten and Nefertiti were shown in the Window of Appearances (fig. 2) on the northern side of the western wall (Davies, 1941, pl. XXXIII). On the same wall, we can also see Ramose (Davies, 1941, pl. XXXIV-XXXV) with arms raising up. The vizier's neck, as well as the hands, are festooned with golden necklaces.

Texts always accompany the reliefs. The king's speech accompanies the rewarding scenes. In the speech, the pharaoh clearly gives the reasons why the dignitary was so generously awarded, and thus appreciated for his merits for the country and for the king. The official in his response always emphasised his gratitude for the goods he received and the honours given to him (Schulman, 1988, p. 116).

As already mentioned, the gifts of gold were a great honour to the officials and probably became an unforgettable and unique moment in their lives. The confirmations of this phenomenon can be found in the tombs of such lucky people. On the walls of the burial chambers, we can see the moment of giving the necklaces by the king. But the history was often described further - both in the texts and the reliefs. The dignitary - of course with his gold necklaces on the neck - was coming home, driving his chariot, where his family and friends were waiting for him ${ }^{13}$. During the feast the official still proudly wore the necklaces ${ }^{14}$. There are even examples where the dignitary performed the cult ceremony wearing gold jewellery received from the ruler ${ }^{15}$.

${ }^{13}$ E.g.: The scene from the tomb of Meryre II: Davies, 1905, vol. 2, pl. XXXVI.

${ }^{14}$ E.g.: The scene from the tomb of Any: Davies, 1908, vol. 5, pl. IX.

${ }^{15}$ E.g.: The scene from the tomb of Meryre: Davies, 1903, vol. 1, pl. XXXV, XXXVII. 


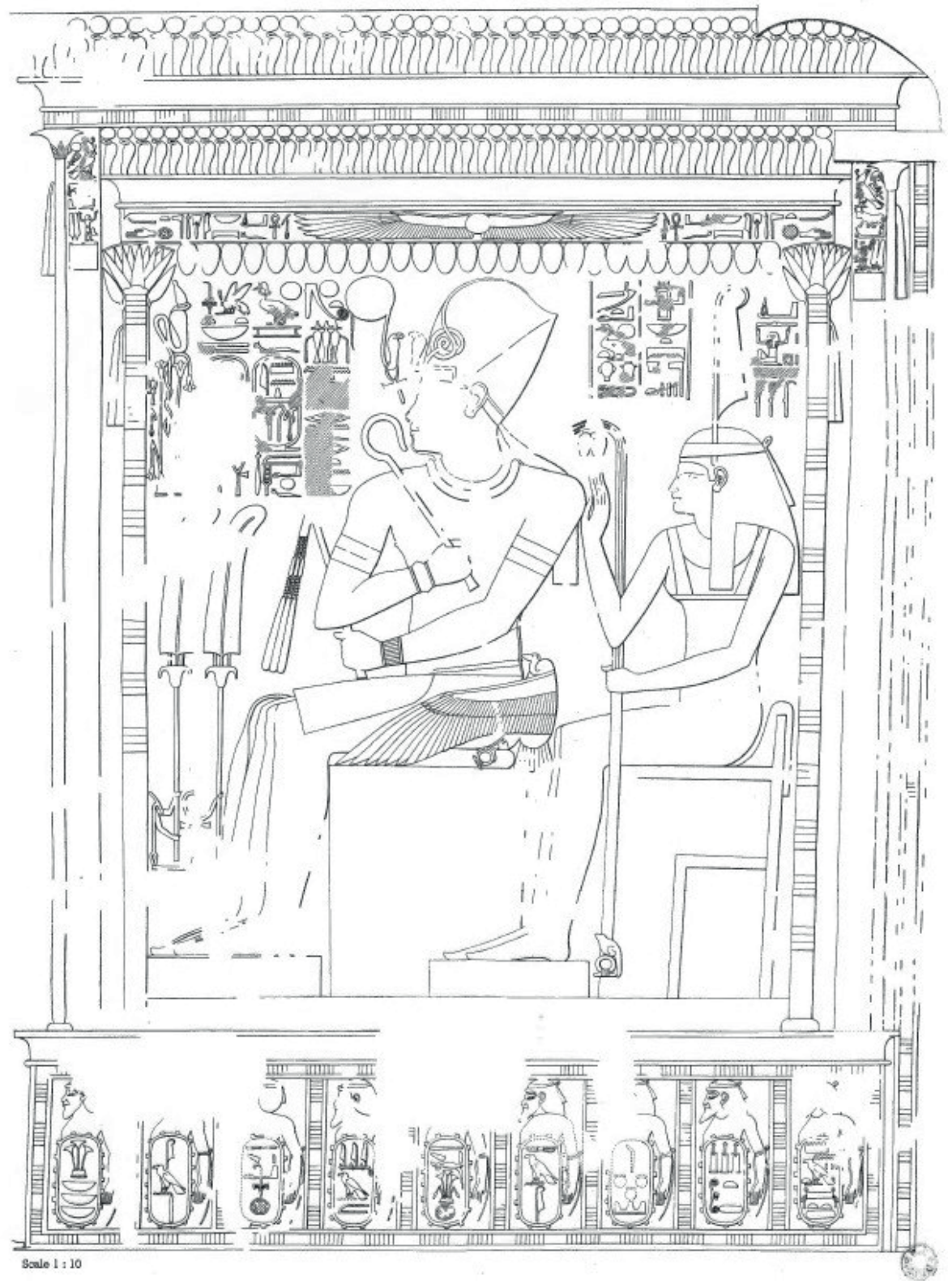

Fig. 1. Amenhotep III and the goddess Maat. The tomb of Ramose (TT55) (Davies, 1941, pl. XXIX) 


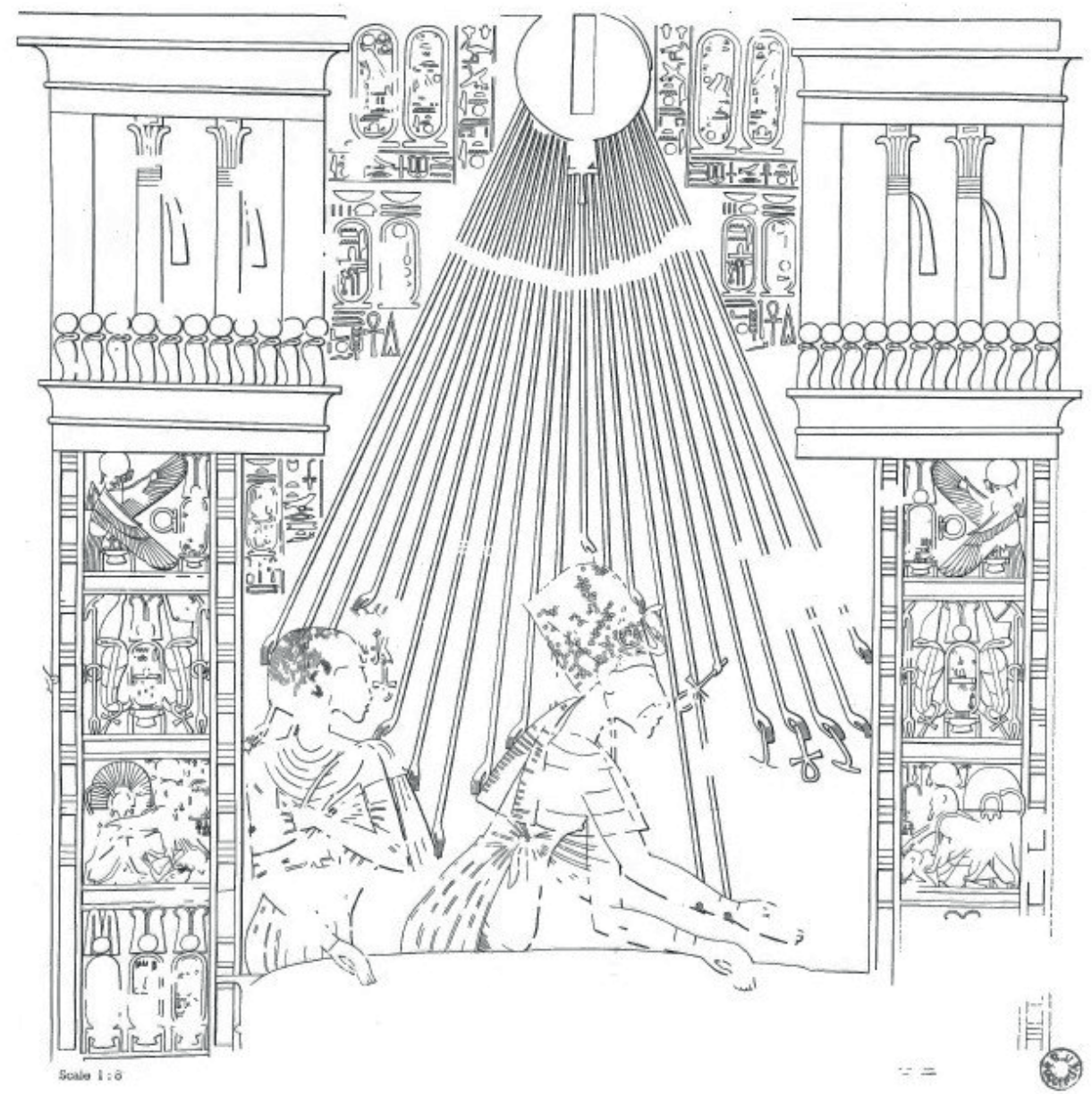

Fig. 2. Akhenaten and Nefertiti in the Window of Appearance. The tomb of Ramose (TT55) (Davies, 1941, pl. XXXIII)

The gold gifted by the pharaohs is worth attention too. The gold always occurs in the form of necklaces. The Egyptian word used to describe this metal, $n b w$, has been written with hieroglyph in the shape of a gold necklace with hanging beads and a clasp<smiles>[C+]1=CCC=C1</smiles>

(S12). This specific type of necklace, which appears in the discussed scenes, was referred to the Egyptians as šby.w. The jewellery consisted of four strings of very tightly threaded and heavy beads with a lenticular shape (Aldred, 1978, photo 36, p. 118). 
Why was the gold given? For the ancient Egyptians, as even for many modern civilisations, gold was the most valuable of ores. It was believed that the bodies of the gods were pure gold, so it was also the colour of divinity (Andrews, 1994, p. 105).

In the beginning, only the private men and women were shown in the gold necklaces, which were used to honour the deserved subjects (Pereyra De Fidanza, 2000, p. 173-184). Since the reign of Amenhotep II (XVIII dynasty), the kings were also shown on the reliefs in the honoured officials' tombs. In the Ramesside Period, also the rulers were more commonly imaged wearing jewellery of this type (Lexikon der Ägyptologie II, col. 732).

The scenes of the gold giving were placed almost only in the private tombs. There is a fragment of the relief from Medinet Habu (Hölscher, 1932, p. 25, fig. 18) on which the king's torso is visible. He bends over the balustrade handing the gold necklace to the dignitary.

\section{THE TYPES OF SCENES OF REWARDING DIGNITARIES}

The Amarna reliefs are characterised by specific dynamics of representations. The royal couple was very often shown in motion or in specific intimate poses, which were unusual in ancient Egypt. The same applies to the scenes of rewarding dignitaries with gold necklaces. During the reign of Amenhotep III, in the scenes of gifting with gold, the king was shown in passively - he only sat on the throne, whereas Akhenaten, often together with his family, was shown actively.

The good examples illustrating the difference in the manner of rewarding the officials could be the reliefs from the tomb of Kheruef (TT192) and Ramose (TT55), and of course, the reliefs from the Amarna tombs.

In the tomb of Kheruef in Thebes Amenhotep III is shown giving the gold necklaces (fig. 3) to the Steward of the Great Royal Wife Tiye (The Tomb of Kheruef 1980, pl. XXIV). The pharaoh sits on a throne in a stiff pose, and the goddess Hathor sits behind him on the second throne. Behind the goddess stands queen Tiye. The king holds the scepters of nekhakha and heka in the crossed arms, and he wears the Sekhemty Crown on his head. All three figures are shown inside the kiosk decorated with friezes of uraeuses. The pharaoh offers to Kheruef four gold necklaces on the small table in front of the kiosk. However, the gesture of handing out jewellery is not presented, which is a crucial difference in comparison to the scenes where Akhenaten and his family personally hand or throw necklaces from the Window of Appearances.

One of the oldest scenes of giving out gold necklaces from the Window of Appearance is the mentioned above relief from the tomb of Ramose (Davies, 1941, pl. XXXIII). The representation is located on the same wall where Amenhotep III while sitting on the throne, in the company of the goddess Maat, is handing the gold necklaces to the dignitary (fig. 1). The scene with Amenhotep III is located to the left of the entrance to the second chamber of the tomb (southern part of the western wall), while the scene with the Amarna royal couple and Aten (fig. 2) was immortalised to the 


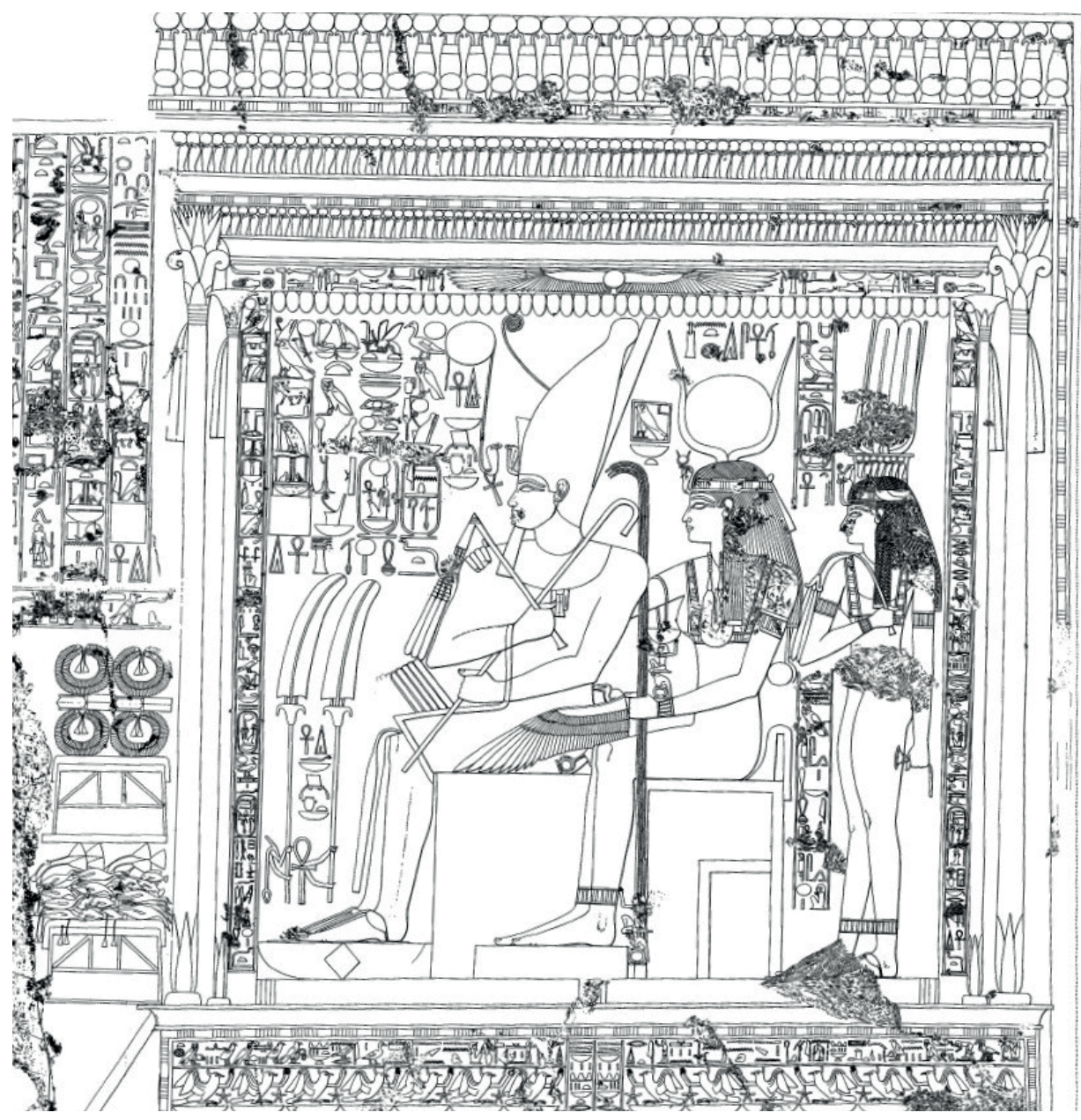

Fig. 3. Amenhotep III during giving gold Kheruef (The Tomb of Kheruef, 1980, pl. XXIV)

right of the entrance (north part of the western wall). In the Window of Appearance, Akhenaten and Nefertiti are shown alone without their children. It is worth noting that the discussed relief is one of the first representations of the queen herself. Nefertiti was shown in a very passive pose - as an observer of events, not their performer. The pharaoh leans slightly forward through the balustrade of the balcony in a gesture of greeting Ramose. Above the royal couple rises Aten, who holds the sign of life - ankh, and the sign of the power - uas in his hands.

In the tomb of the Steward of the queen Tiye, Hui (Davies, 1905, vol. 3, pl. XVIXVII), the royal couple was also imagined alone in the Window of Appearance ${ }^{16}$. The

16 The scenes of giving gold to dignitaries were described according to types of performances, not chronologically. 
relief is not well preserved. However the figure of Akhenaten in Khepresh Crown and Nefertiti in the Nubian wig (?) are still visible. On the western side of the northern wall of the tomb, we can see a scene very similar to that of the Ramose tomb, but in this case both the king and queen lean towards the dignitary to greet him (Davies, 1941, pl. XVI). In turn, on the eastern side of the same wall (Davies, 1941, pl. XVII), the royal couple throws gold necklaces towards the Hui. Right next to the Window of Appearances, two of the oldest princesses, Meritaten and Maketaten, were shown. The sisters are hugging each other. They have the sidelock of youth on their heads, and the dresses are identical like their mother's. Above the royal couple rises up the sun disc of the Aten.

A similar arrangement of the scene preserved on the relief (fig. 4) in the tomb of Parennefer - Cupbearer of the King (Davies, 1908, vol. 6, pl. IV). Nefertiti is shown in the Blue Flat-topped Crown, and Akhenaten has a Khepresh Crown on his head. The queen rests both hands on the balustrade of the window while the slightly bowed pharaoh reaches to the hand of the dignitary. The necklaces, which will be given to Parennefer, lie on the small table opposite to the royal couple. In the next scene, the official is shown festooned with gold. This time, the king and queen are accompanied by three princesses: Meritaten, Maketaten, and Ankhesenpaaten, and sister of the queen, Mutnodjemet. The girls have the sidelock of youth on their heads and characteristic pleated dresses. Aten rises above the royal couple's heads and puts ankh sign under the noses of the king and the queen, but this time he also hands them a small cobra.

In the tomb of Panehesy - The First Servant of the Aten in the House of Aten in Akhetaten (Davies, 1905, vol. 2, pl. X), Akhenaten and Nefertiti are shown in the Window of Appearance and are accompanied by the eldest daughter, Meritaten. The Pharaoh, with the Khepresh Crown on the head, greets Panehesy, leaning slightly towards him and holding out his hand to him. Nefertiti in Blue Flat-topped Crown embraces one of the princesses with one hand, and the other arm embraces her husband. Next to the Window of Appearances, the other three sisters Maketaten, Ankhesenpaaten, and Neferneferuaten Tasherit, hug each other.

In the tomb of the Greatest of Seers of the Aten in Akhetaten, Meryre I (Davies, 1903, vol. 1, pl. VI), the scene of giving gold is significantly damaged. Therefore, we cannot even determine the royal couple's pose on the relief but, surely, Meritaten was shown with her parents.

Akhenaten and Nefertiti were accompanied by an increasing number of daughters. Three princesses were presented in the Window of Appearances with their parents in the tombs of the Chamberlain of the Lord of the Two Lands, Tutu (Davies, 1908, vol. 6, pl. XIX), and Ai - the later king of Egypt (Davies, 1908, vol. 6, pl. XXIX). Unfortunately, in the Tutu tomb, the part of the relief with girls was cut out, but thanks to the surviving hieroglyphs, we know that Meritaten, Maketaten, and Ankhesenpaaten were shown next to Nefertiti. In turn, one of the most beautiful scenes of rewarding the official was immortalised in the tomb of Ai (fig. 5). Akhenaten in the Khepresh Crown is giving the necklaces to his father-in-law, Ai, and the 


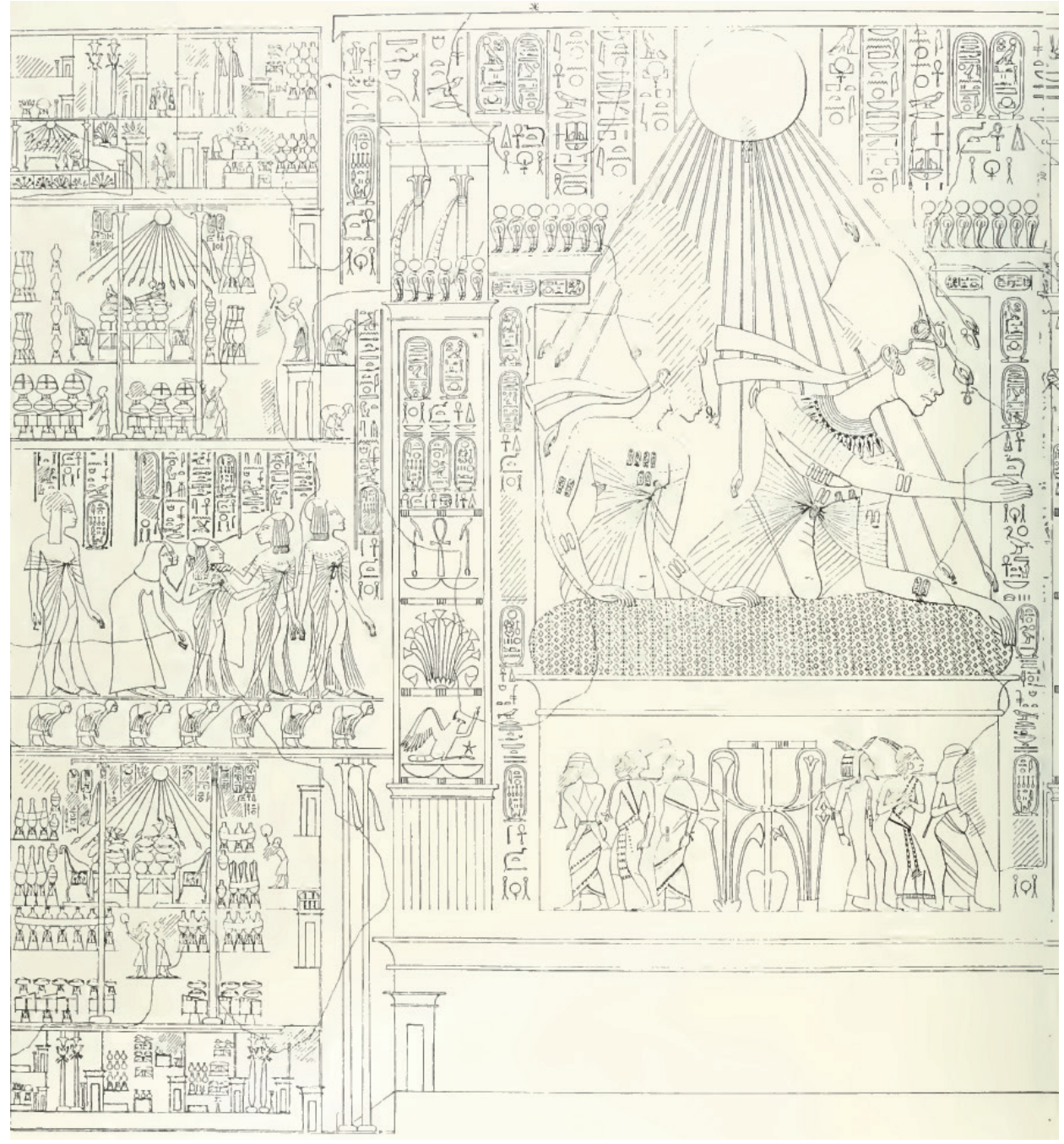

Fig. 4. Royal couple in the Window of Appearance. The tomb of Parennefer, Akhetaten (Davies, 1908, vol. 6 , pl. IV)

nurse of his wife, Tei ${ }^{17}$. Nefertiti is shown with the same gesture. Queen hands over two necklaces to her father and her nurse. Nefertiti has a Blue Flat-topped Crown on her head, which is very richly ornamented with uraeuses and ribbons. Nefertiti throws gold with one hand and protects one of the princesses who stands on the balustrade of the Window of Appearances with her second arm. It is most likely Ankhesenpaaten. The queen strokes the daughter's head while the princess reciprocates the act of love by touching

${ }^{17}$ One should note that it was extremely uncommon for a woman to receive such gift. It emphasizes the crucial meaning of Tei. 
her mother's chin. At the right shoulder of Nefertiti, also on the balustrade, stands Maketaten, who, with one arm, entwines the mother's neck and holds the necklaces in the other hand. Next to Nefertiti stands Meritaten ${ }^{18}$ with a tray in hand on which the necklaces rest. The princess throws one of the necklaces to her grandparents, Ai and Tei.

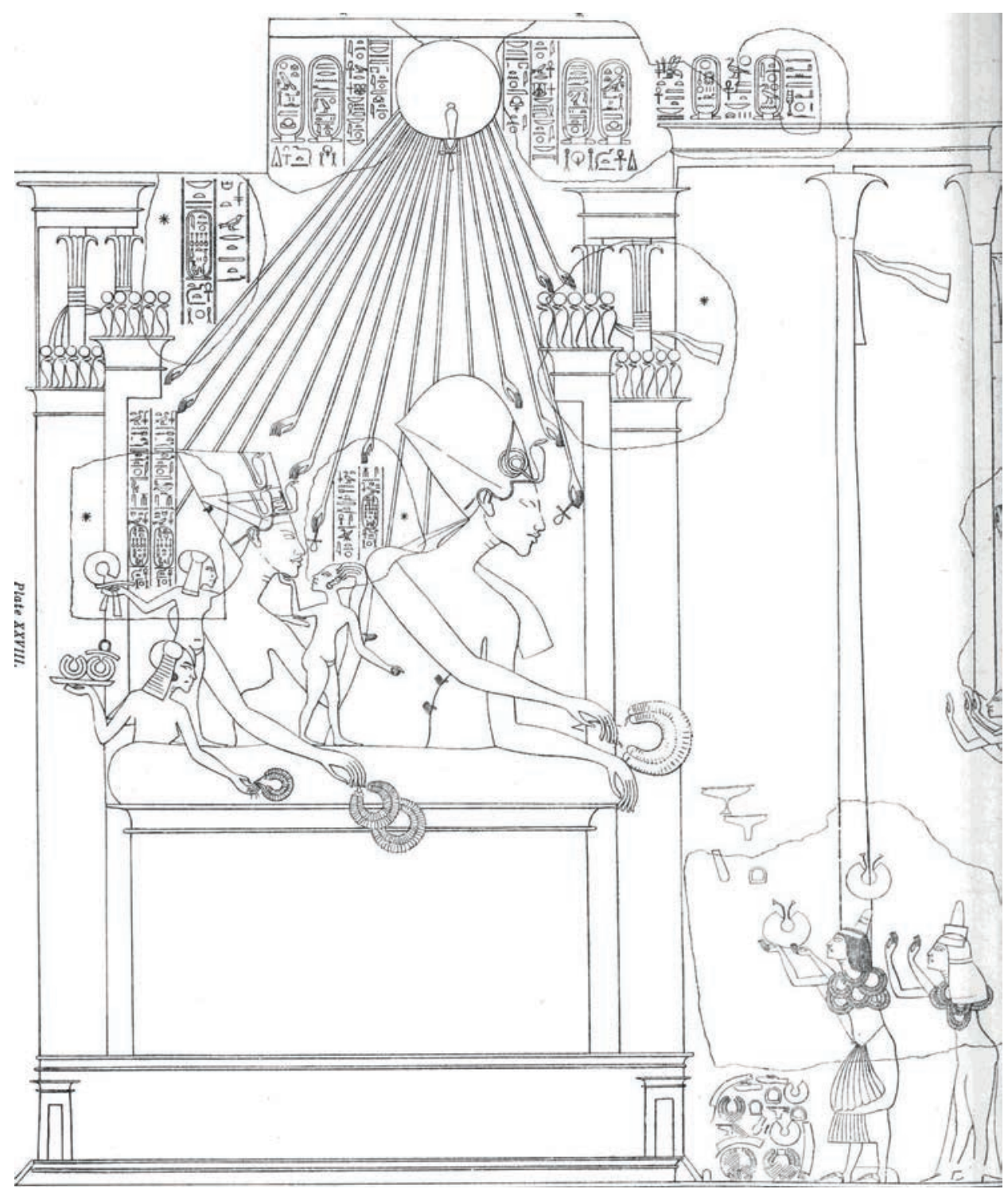

Fig. 5. Royal family in the Window of Appearance. The tomb of Ai, Akhetaten (Davies, 1908, vol. 6, pl. XXIX)

18 More about the infant iconography of Amarna Period Princesses: Kloska, 2017. 
In the tomb of Meryre II - Overseer of the House in the Royal Quarters of the Great Royal Wife Neferneferuaten Nefertiti (Davies, 1905, pl. XXXIII-XXXIV), the scene of giving the gold necklaces looks differently (fig. 6). Akhenaten and Nefertiti stand in the Window of Appearances in their standard garments and crowns. The king throws the necklace in the direction of the dignitary. Nefertiti, who stands right next

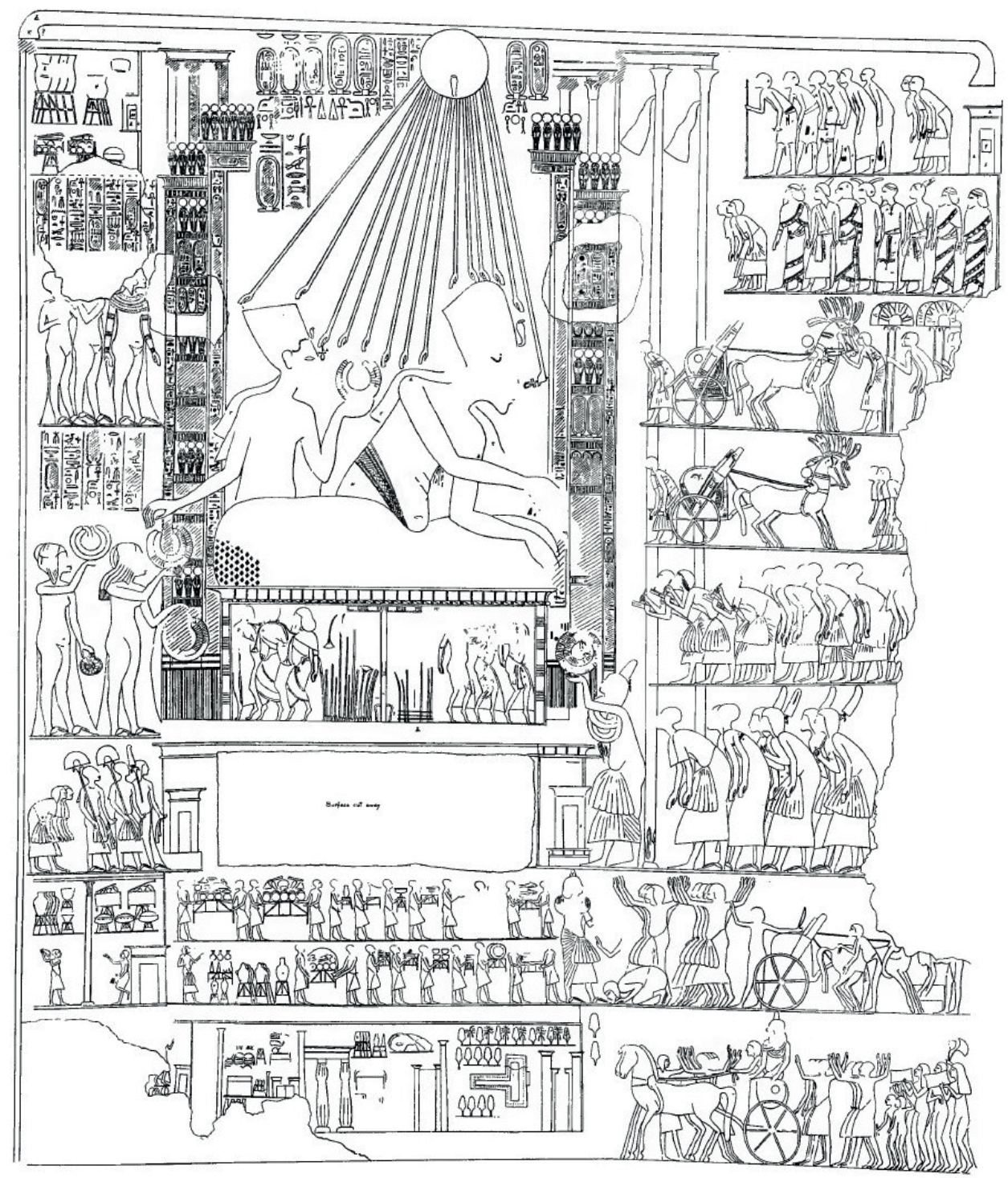

Fig. 6. The royal couple in the Window of Appearance. The tomb of Meryre II, Akhetaten (Davies, 1905, vol. 2, pl. XXXIII) 
to her husband, gives him the necklace with one hand, while another necklace is put in queen's hand by Meritaten. The princess, together with her younger sister Maketaten, is imagined at the Window of Appearances. They hold several necklaces in their hands, which they hand over to the mother in turns. The younger sisters are standing nearby: Ankhesenpaaten, Neferneferuaten Tasherit, and Neferneferure, who appears on relief for the first time. The two youngest girls hug each other while the older one is watching her parents.

It should be emphasised that in the Amarna iconography, there are two more types of the scenes for giving out gold to the royal dignitaries. The first type may be observed in the tomb of Penthu - Chamberlain and the First Servant of the Aten in the Mansion of the Aten in Akhetaten (Davies, 1906, vol. 4, pl. VIII). The Window of Appearances was not presented here. The relief shows Akhenaten and Nefertiti sitting on the thrones during the ceremony. Because of damages, only the pharaoh is visible. He sits on the chair with the symbol of sema-taui. Behind him is a niche cut down at a later time, where probably Nefertiti was shown. Penthu festooned with the gold necklaces stands in front of the royal couple.

The second type of the scene of gifting the gold was presented in this very same tomb (Davies, 1906, vol. 4, pl. VII-VIII). This time the ceremony takes place in the courtyard. The royal couple with the gesture of greeting is shown standing up in front of the honoured subject. Unfortunately, relief is also severely damaged. A similar and better-preserved scene was found in the tomb of Meryre I (Davies, 1903, vol. 1, pl. XXX), where Akhenaten and Nefertiti stand in the courtyard. Behind the parents, there are two princesses, probably the oldest ones. The younger is holding her older sister by the arm. Opposite the royal family stands Meryre I festooned with gold ${ }^{19}$.

As we can notice, Akhenaten and Nefertiti are giving the gold to the dignitaries mostly from the Window of Appearances. The pharaoh is shown in a slightly bent pose while he greets the official, or he throws the necklace towards the recipient. In turn, $\mathrm{Ne}$ fertiti initially acted only as a mere observer of the events. However, the queen quickly became part of the ceremony - she is giving the necklaces to her husband or throwing gold in the direction of dignitaries. Despite the formal and official nature of the ceremonies, the royal couple - similarly to other types of scenes - often was accompanied by the daughters. They sometimes help their parents, for example by giving them necklaces, but they are also often shown as typical children, that is, busy with themselves or showing love to their mother.

The girls were born at different times, so it is possible that over the years of the Akhenaten's reign, the number of daughters shown on the reliefs was growing - because it was growing in real life. If we accept such assumption, the number of princesses can serve as a dating marker.

19 An analogous scene is located in the tomb of Meryre II (Davies, 1905, vol. 2, pl. XLI). However, the gold necklaces are not given by Akhenaten and Nefertiti, but by Akhenaten's co-ruler, the pharaoh Smenkhkare, who is accompanied by his Great Royal Wife, Meritaten. 


\section{CONCLUSIONS}

As it was shown, the popularity of the architectural construction, which is the Window of Appearance, is closely related to the introduction of a new religious system by Akhenaten and Nefertiti. The window was a place where the pharaoh-priest - often together with his family - could meet his subjects. It was crucial because the king was a kind of intermediator between the people and the only right sun god, Aten.

The characteristic shape of the Window of Appearance often appears in the architecture and art of the Amarna Period. This structure resembles the $3 h t$ hieroglyph, which is the morning sun rising between two hills. This symbol is a part of the name of the new capital 3ht-itn - The Horizon of Aten.

In the Pyramid Texts it was written that the horizon is the place where the pharaoh and the sun become the highest cosmic and celestial spirits - Egyptian 3h, which seems to have influenced the Amarna king who changed his name from Amenhotep (Amun is satisfied) to Akhenaten (The one, that is useful for Aten or The Ach of the Aten).

The words $3 h t$ and $3 h$ could also have a connection to the word $3 h w$, which means magical power/energy. Atum used this energy to create his children, Shu and Tefnut, whose Amarna equivalents are Akhenaten and Nefertiti.

The Window of Appearance was a magical place connecting the Egyptian subjects with the highest god, thanks to the help of the high priest, who was the pharaoh. The king himself, by crossing the horizon, could become a celestial being unattainable for ordinary people.

In the Window of Appearance, Akhenaten very often appeared together with $\mathrm{Ne}$ fertiti and their daughters. It is possible that the whole royal family had a special religious status. The images of the Amarna couple, together with the Aten and the children, were carved on the stelas to which people prayed. Hence, we can assume that the whole family performed as a divine Ennead similar to that of Heliopolis.

The Window of Appearance also became a place where the deserved dignitaries were rewarded with gold necklaces. Initially, the Akhenaten was giving the jewellery, but later he was also joined by Nefertiti and thereafter also the daughters of the royal couple.

\section{REFERENCES}

Aldred, C.

1978 Jewels of the Pharaohs: Egyptian Jewelry of the Dynastic Period. New York: Ballantine Books.

Andrews, C.

1994 Amulets of Ancient Egypt. London: British Museum Press.

Borchardt, L.

1913 Das Grabdenkmal des Königs S'ahu-Re, vol. 2.2: Die Wandbilder: Abbildungsblätter. Leipzig: Hinrichs. 
Bunson, M. R.

2012 Encyclopedia of Ancient Egypt ( ${ }^{\text {rd }}$ edition). New York: Facts on File Publications.

De Buck, A.

1955 The Egyptian Coffin Texts. Texts of Spells 76-163, vol. 2. Illinois: The University of Chicago Oriental Institute Publications.

Garis Davies, N. de

1903 The Rock Tombs of Amarna, vol. 1: The Tomb of Meryra. London: Egypt Exploration Society.

1905 The Rock Tombs of Amarna, vol. 2: The Tombs of Panehesi and Meryra II. London: Egypt Exploration Society.

1905 The Rock Tombs of Amarna, vol. 3: The Tombs of Huya and Ahmes. London: Egypt Exploration Society.

1906 The Rock Tombs of Amarna, vol. 4: The Tombs of Penthu, Mahu and Others. London: Egypt Exploration Society.

1908 The Rock Tombs of Amarna, vol. 5: Smaller Tombs and Boundary Stelae. London: Egypt Exploration Society.

1908 The Rock Tombs of Amarna, vol. 6: The Tombs of Parennefer Tutu and Ay. London: Egypt Exploration Society.

1941 The Tomb of the Vizier Ramose. London: Egypt Exploration Society.

Erichsen, W.

1933 Papyrus Harris I. Hieroglyphische Transkription. Bruxelle: Fondation Égyptologique Reine Élisabeth.

Friedman, F.

1986 3h in the Amarna Period. Journal of the American Research Center in Egypt, 23, 99-106.

Gardiner, A. H.

1957 Egyptian Grammar. Being an Introduction to the Study of Hieroglyphs. Oxford: Griffith Institute, Ashmolean Museum.

Hanning, R.

1995 Die Sprache der Pharaonen. Großes Handwörterbuch Ägyptisch-Deutsch (2800-950 v. Chr.). Mainz: Philipp von Zabern.

Helck, W., Otto, E., Westendorf, W. (eds)

1977 Lexikon der Ägyptologie II (cols. 731-733). Wiesbaden: Harrassowitz Verlag.

Hölscher, U.

1932 Oriental Institute Communications, No. 15. Excavations at Ancient Thebes 1930/1931. Chicago - Illinois: University of Chicago Press.

Kemp, B. J.

1976 The window of appearance at El-Amarna and the basic structure of this city. Journal of Egyptian Archaeology, 62, 81-99.

1995 Outlying temples at Amarna. In B. J. Kemp (ed.), Amarna Reports VI (p. 411-462). London: Egypt Exploration Society.

2013 The city of Akhenaten and Nefertiti: Amarna and its people. London: Thames \& Hudson. Kloska, M. M.

2013 Formy przedstawień boga Atona w sztuce Okresu Amarneńskiego. Medjat - Studia Egiptologiczne, 1, 96-118.

Kruchten, J.-M.

1981 Le Décret d'Horemheb. Traduction, commentaire épigraphique, philologique et institutionnel. Bruxelles: Editions de l’Université de Bruxelles.

Martin, G. T.

1974 The Royal Tomb at El-Amarna, vol. 2: The Reliefs, Inscriptions, and Architecture. London: Egypt Exploration Society. 
Pendlebury, J. D. S.

1951 The City of Akhenaten. Part III: The Central City and the Official Quarters. The Excavations at Tell el-Amarna during the seasons 1926-1927 and 1931-1936 [Memoir of the Egypt Exploration Society 44]. London: Egypt Exploration Society.

Pereyra De Fidanza, V.

2000 A queen rewarding a noblewoman in TT49. In K. M. Ciałowicz, J. A. Ostrowski (eds), Les civilisations du bassin Méditerranéen: Hommages à Joachim Śliwa (p. 173-184).

Redford, D. B. Cracovie: Université Jagellonne Press.

1988 The Akhenaten Temple Project, Rwd-Mnw and Inscriptions, vol. 2. Toronto: University of Toronto Press.

Roth, S.

2002 Gebieterin aller Länder: die Rolle der königlichen Frauen in der fiktiven und realen Außenpolitik des ägyptischen Neuen Reiches. Freiburg: Universitätsverlag Freiburg (Orbis Biblicus et Orientalis 185).

Schulman, A. R.

1988 Ceremonial Execution and Public Rewards: Some Historical Scenes on New Kingdom Private Stelae (Phd dissertation). University of Zurich.

The Epigraphic Survey, Department of Antiquities of Egypt

1980 The Tomb of Kheruef. Theban Tomb 192. Chicago: The Oriental Institute.

Vomberg, P.

2004 Das Erscheinungsfenster innerhalb der amarnazeitlichen Palastarchitektur: HerkunftEntwicklung - Fortleben (Philippika: Marburger altertumskundliche Abhandlungen 4). Wiesbaden: Harrassowitz Verlag.

2008 Kult und Architektur. In Ch. Tietze (ed.), Amarna: Lebensräume - Lebensbilder - Weltbilder (p. 64-85). Potsdam: Arcus.

Williamson, J.

2016 Nefertiti sun temple: A new cult complex at Tell el-Amarna, vol. 1. Harvard Egyptological Studies. Leida: Brill.

\section{THE SYMBOLISM AND FUNCTI ON OF THE WINDOW OF APPEARANCE IN THE AMARNA PERIOD}

\section{Streszczenie}

Rządy Achenatona i Nefertiti charakteryzuje nie tylko specyficzny styl ikonograficzny, ale również rodzaje scen. Jednymi z najbardziej charakterystycznych przedstawień znanych ze ścian grobowców w Achetaton są reliefy ukazujące wręczanie złota dostojnikom. W czasach rządów amarneńskiej pary królewskiej wręczanie złota dostojnikom odbywało się (prawie zawsze) z tak zwanego Okna Pojawień, z którego Achenaton wraz z Nefertiti i córkami honorowali oddanych i zasłużonych dostojników. Okno Pojawień stało się więc elementem architektonicznym ściśle powiązanym z obowiązkami religijnymi i administracyjnymi pary królewskiej, a pałace w Achetaton dostosowano pod względem zabudowy specjalnie na tę okoliczność, umiejscawiając w nich te charakterystyczne konstrukcje.

Okno Pojawień możemy opisać jako balkon z dwoma bocznymi wysokimi filarami, bogato ozdobionymi rzędami ureuszy oraz gzymsem cavetto. Dla Okna Pojawień charakterystycznym detalem 
była duża poduszka leżąca na poręczy balustrady oraz charakterystyczne motywy ikonograficzne znajdujące się pod tą konstrukcją - balustradę balkonu często zdobił motyw sema-taui oraz pojmani jeńcy.

Wygląd Okna Pojawień to wynik ewolucji tradycyjnego egipskiego kiosku, w którym ukazywano faraona często w towarzystwie jakiegoś bóstwa i/lub małżonki. Od początku XVIII dynastii do panowania Amenhotepa III kiosk znacznie się powiększył, co widoczne jest na reliefach dzięki potrójnym fryzom ureuszy. Ostatecznie zmiany w wyglądzie kiosku doprowadziły do wykształcenia się w czasach rządów Achenatona charakterystycznego Okna Pojawień.

Z zachowanych reliefów wynika, że Okna Pojawień musiały wychodzić na duży dziedziniec, który był w stanie pomieścić sporą liczbę poddanych, często towarzyszących obdarowywanemu oficjelowi.

Okna Pojawień odkryto zarówno w świątyniach grobowych, jak i pałacach królewskich okresu Nowego Państwa. Jednakże rozkwit oraz częstotliwość występowania tego elementu architektonicznego oraz jego popularność przypada na Okres Amarneński. Najwcześniejszy znany przykład Okna Pojawień pochodzi ze Świątyni Milionów Lat królowej Hatszepsut w Deir el-Bahari.

Przez lata wykopalisk, prowadzonych na stanowisku w Tell el-Amarna, archeolodzy nie potrafili zlokalizować żadnego Okna Pojawień. Na podstawie uwiecznionych scen można wnosić, że istniało więcej niż jedno okno, z którego faraon wraz z Nefertiti i córkami mógł sprawować swoje administracyjne obowiązki. Obecnie sądzi się, że okna mogły znajdować się między innymi w Domu Króla, Wielkim Pałacu, Pałacu Północnym, kompleksie Kom el-Nana oraz Małej Świątyni Atona.

Nowa religia, jaką wprowadzili Achenaton i Nefertiti, wymuszała wiele zmian, jakie należało poczynić w architekturze - zwłaszcza w świątyniach i pałacach. W związku z tym, że bóg Aton przyjął formę dysku solarnego, który widoczny był dla każdego Egipcjanina, mroczne sanktuaria, takie jak te dedykowane Amonowi, przestały być potrzebne.

Zmiany wprowadzono także w architekturze pałacowej. Wynikały w dużej mierze z nowego systemu religijnego, w którym Achenaton i Nefertiti stanowili parę boskich bliźniąt na wzór Szu i Tefnut, którzy według teologii heliopolitańskiej byli dziećmi boga stwórcy Atuma, którego w Amarnie zastępował Aton. Para królewska modliła się do głównego słonecznego boga, podczas gdy ich poddani modlili się do nich samych. W związku z tym, że Achenaton pełnił rolę kapłana, dzięki któremu lud mógł kontaktować się z bogiem, należało stworzyć konstrukcję, która umożliwiałaby królowi na publiczne spotkania z poddanymi. Taką innowacją architektoniczną stało się właśnie Okno Pojawień, w którym Egipcjanie widywali nie tylko faraona, ale całą ubóstwioną rodzinę.

Po Okresie Amarneńskim Okna pojawiają się wyłącznie w pałacach i całkowicie tracą swój kultowy charakter. Używano ich wyłącznie do celów formalnych, takich jak uhonorowywanie zasłużonych poddanych

Kształt typowego Okna Pojawień jest dobrze widoczny na reliefach znajdujących się w amarneńskich grobowcach. Forma, jaką przyjęła ta architektoniczna innowacja, nie jest przypadkowa. Balustrada okna, za którą stała rodzina królewska, dwa boczne filary oraz brak nadproża sprawiają, że Okno Pojawień przyjmuje charakterystyczny kształt hieroglifu 3ht, który przedstawia słońce wschodzące między dwoma górami (wadi). Okno Pojawień miałoby stanowić zatem metaforę. Należy zaznaczyć, że w Tekstach Piramid napisano, że horyzont, czyli ’̧ht jest miejscem, gdzie król i bóg słońce stają się 3h , czyli kosmicznym i niebiańskim bytem/duchem.

Okno Pojawień miało więc być magicznym miejscem łączącym lud egipski z najwyższym bogiem za pomocą kapłana, którym był faraon. Jednocześnie sam faraon, przekraczając horyzont, mógł stać się niebiańskim bytem, nieosiągalnym dla zwykłych ludzi.

Okno Pojawień stało się również miejscem, gdzie złotymi naszyjnikami nagradzano zasłużonych dostojników. Początkowo biżuterią obdarowywał wyłącznie król, później także królowa i często córki pary królewskiej. 